\title{
A Case of Intraorbital Hemangioma Diagnosed with Tc 99m Labeled Erythrocyte Scintigraphy and Magnetic Resonance Imaging
}

\author{
Tc 99m Işaretli Enitrosit Sintigrafisi ve Manyetik Rezonans Görüntüleme ile \\ Tanı Konulan Bir Intraorbital Hemanjiom Vakası
}

\author{
Tansel Ansal Balal', Zehra Pinar Kocl, Burak Turgut2, Ayse Murat Aydın³, Bedriye Busra Demirell \\ I Firat University Medical Faculty, Departments of Nuclear Medicine, Elazig, Turkey \\ 2 Firat University Medical Faculty, Departments of Nuclear Medicine Ophtalmology, Elazig, Turkey \\ 3 Firat University Medical Faculty, Departments of Nuclear Medicine Radiology, Elazig, Turkey
}

\begin{abstract}
We present a 20 year-old male patient who had prominent positional proptosis of the right eye and admitted to the hospital for tonsillectomy operation. After conventional ophthalmological examination, magnetic resonance imaging (MRI) and Tc 99m labeled erythrocyte scintigraphy were performed to confirm the diagnosis. Although it is rare to perform scintigraphy for this pathology, the visualization of intraorbital hemangioma was very obvious and we would like to present the visualization of the intraorbital hemangioma both with scintigraphy and MRI. (MIRT 2011 ; 20: 26-8)

Key words: Hemangioma, Technetium Tc $99 \mathrm{~m}$ pyrophosphate, orbital neoplasms, radionuclide imaging, magnetic resonance imaging
\end{abstract}

\section{Özet}

Sağ gözde belirgin propitozisi olan ve hastaneye tonsillektomi operasyonu için bașvuran 20 yașında erkek hastayı sunuyoruz. Rutin göz muayenesi sonrasında tanının doğrulanması amacıyla manyetik rezonans (MR) görüntüleme ve Tc $99 \mathrm{~m}$ işaretli eritrosit sintigrafisi yapılmıștır. Her ne kadar bu patoloji için sintigrafi yapılması nadir bir uygulama olsa da bu vakada intraorbital hemanjiom çok net olarak görüntülenmiștir ve biz de bu intraorbital hemanjiom vakasını MR ve sintigrafi görüntüleriyle sunmak istiyoruz. (MIRT 201 1; 20: 26-8) Anahtar kelimeler: Hemanjiom; teknesyum Tc $99 \mathrm{~m}$ pirofosfat; orbita tümörleri; radyonüklit görüntüleme; manyetik rezonans görüntüleme

\section{Introduction}

The most common benign orbital tumors of the childhood are hemangiomas (1). Capillary hemangioma is a benign vascular lesion that is usually not apparent at birth, but it proliferates during the first year of life and regresses about age seven (2). Periorbital hemangiomas are usually involute and cause no ocular pathology (3). However, amblyopia is the most frequent complication. The others are strabismus, ptosis, proptosis, exposure keratopathy and optic atrophy (4).
Our case presented with proptosis, especially during the hyperflexion of the neck. Scintigraphic imaging of orbital tumors is a rare approach during the diagnostic course. However, in some previously reported cases, Tc $99 \mathrm{~m}$ labeled erythrocyte imaging was used and the diagnosis was confirmed with histopathological results (5). Differentiation of the hemangioma from vascular malignant tumors might be difficult by MRI for some cases but MRI can identify the lesion borders, nature and relationship with the adjacent soft tissue structures. Confirmation of the diagnosis of these tumors by

Address for Correspondence: Tansel Ansal Balcı, Firat University Hospital, Department of Nuclear Medicine, 23119, Elazig, Turkey

Phonel: +90 42423335 55/2095 Fax: +90 4242388096 E-mail: tansel_balci@yahoo.com

Received: 19.07.2010 Accepted: 22.10.2010

Molecular Imaging and Radionuclide Therapy, published by Galenos Publishing 
Tc $99 \mathrm{~m}$ labeled erythrocyte imaging which clearly demonstrates hepatic hemangiomas, will be better if the MRI results are suspicious. We present an intraorbital hemangioma case imaged with Tc $99 \mathrm{~m}$ labeled erythrocyte scintigraphy and MRI.

\section{Case Report}

A right sided proptosis in a 20 year-old male patient who underwent tonsillectomy operation was evaluated. He declared that this pathology had existed since his childhood. Ophthalmological examination, MRI and labeled erythrocyte scintigraphy were performed. On ophthalmological examination, mild exophthalmus was present during the hyperflexion of the neck. Visual acuities were 20/20 on both eyes. Although Hertel exophthalmometry could not be
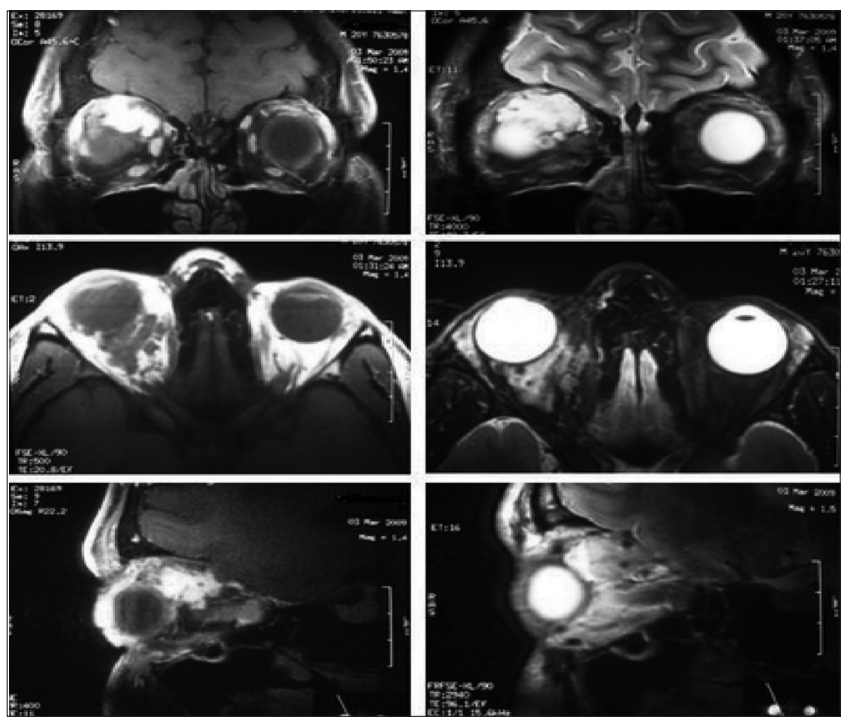

Figure 1. Coronal (T1-w contrast, $T 2 \mathrm{w} /$ out contrast), axial ( $\mathrm{T} 1$ and T2), and sagittal (T1 and T2) slices of MRI

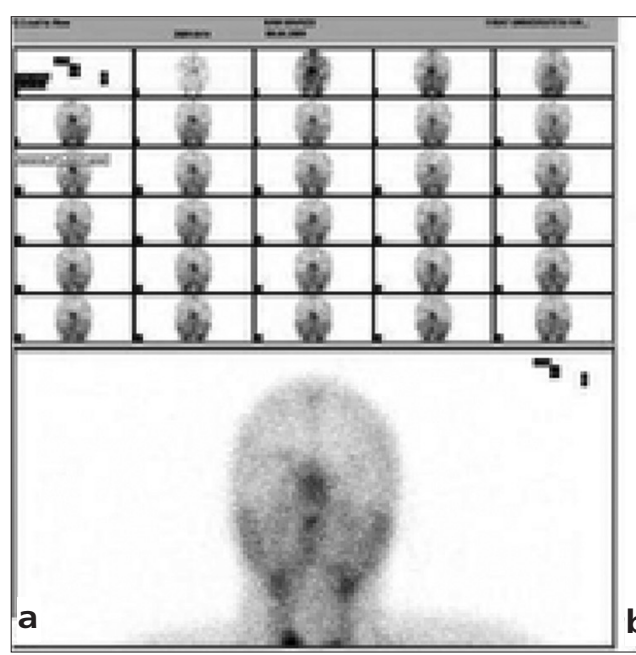

b

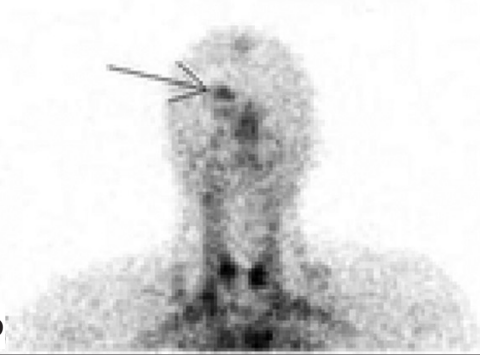

performed, significant proptosis was visually observed on his right eye during the hyperflexion position. Hertel exophthalmometry on primary position measured $11.6 \mathrm{~mm}$ and $11.2 \mathrm{~mm}$ for the right and left eye, respectively. Eye movements were intact. Slit-lamp biomicroscopy and fundus examination did not show any pathological findings. There is no family history. MRI (Figure 1) showed minimal exophthalmus and the lesion which is $3 \times 3 \mathrm{~cm}$ in size. The lesion at the right intraconal localization and causing minimal depletion of the superior rectus muscle showed lobulated borders with signal void areas, isointense on T1-weighted and hyperintense on T2-weighted images. After intravenous contrast injection; the lesion showed intense contrast enhancement.

We performed in vivo labeled Tc $99 \mathrm{~m}$ erythrocyte scintigraphy. Dynamic images showed no vascularisation, and there was slightly increased activity on the early blood-pool images (Figure 2a). Delayed phase planar and SPECT images showed intense tracer accumulation on the lesion localization (Figure 2b, 2c). This typical scintigraphic pattern is known as "perfusion-blood pool mismatch".

\section{Discussion}

The diagnostic test of choice is MRI for intraorbital hemangioma (6) which is characterized by indefinite borders usually penetrating into adjacent tissues. The diagnostic hallmark of the image is numerous vascular structure content of the lesion (7). Tc $99 \mathrm{~m}$ labeled erythrocyte imaging for hemangioma is usually used for the diagnosis of liver hemangiomas. Although there is a significant physiological background tracer accumulation, diagnostic performance of this method for liver lesions is very precise. This technique can also easily demonstrate this kind of tumors even if they are in unusual localization as there is little background activity. Radioactivity accumulation within the lesion of our patient was

Figure 2. Dynamic (serial images on the first rows of 2a), early blood-pool (bottom image of 2a), late phase planar (2b) images on the anterior projection and SPECT (2c-transaxial, sagittal and coronal slices, respectively) images of Tc $99 \mathrm{~m}$ labeled erythrocyte scintigraphy 
very prominent in the late phase images. The scintigraphic pattern of the hemangioma which is hypoactive in the vascular phase and hyperactive in the late phase, is previously well established (8-10). In some studies, this typical appearance of these tumors was used for the differentiation from malignant tumors and confirmed with histopathology (5). According to previous reports, Tc $99 \mathrm{~m}$ labeled erythrocyte imaging could differentiate hemangioma from malignant tumors (5,8-10). This characteristic of Tc $99 \mathrm{~m}$ labeled erythrocyte scintigraphy might help to decide the choice of treatment, i.e. surgery for the malignant lesions or follow-up for the hemangiomas. Finally, appropriate management for hemangiomas is to follow-up by means of clinical and radiological findings and intralesional corticosteroid injection 10 or surgical intervention in some rare situations (11).

\section{References}

1. Henderson JW. Orbital Tumors. In: Holmes S, Hutchison I eds. 3rd ed. New York: Raven Press; 1994. p. 89-95.

2. Hassmann-Poznanska $E$, Krzyna A. Hemangiomas and vascular malformations of the head and neck. Otolaryngol Pol 2006;60:663-674.
3. Ooi KGJ, Wenderoth JD, Francis IC, Wilcsek GA. Selective embolization and resection of a large noninvoluting congenital hemangioma of the lower eyelid. Ophthal Plast Reconstr Surg 2009;25:111-114.

4. Haik BG, Jakobiec FA, Ellsworth RM, Jones IS. Capillary hemangioma of the lids and orbit: an analysis of the clinical features and therapeutic results in 101 cases. Ophthalmology 1979;86:760-792.

5 Polito E, Burroni L, Pichierri P, Loffredo A, Vattimo AG. Technetium $99 \mathrm{~m}-$ labeled red blood cells in the preoperative diagnosis of cavernous hemangioma and other vascular orbital tumors. Arch Ophthalmol 2005;123:1678-1683.

6 Kavanagh EC, Heran MKS, Peleg A, Rootman J. Imaging of the natural history of an orbital capillary hemangioma. Orbit 2006;25:69-72.

7 Sayit E, Durak I, Capakaya G, Yilmaz M, Durak H. The role of Tc $99 \mathrm{~m}$ RBC scintigraphy in the differential diagnosis of orbital cavernous hemangioma. Ann Nucl Med 2001;15:149-151.

8 Gdal-On M, Gelfand YA, Israel O. Tc $99 \mathrm{~m}$ labeled red blood cells scintigraphy: a diagnostic method for orbital cavernous hemangioma. Eur J Ophthalmol. 1999;9:125-129.

9 Front D, Israel O, Groshar D, Weininger J. Technetium-99m-labeled red blood cell imaging. Semin Nucl Med 1984; 14:226-250.

10 Gabdrakhmanova AF, Altynbaeva LR. The first experience in using radionuclide by single-photon emission computed tomography in the diagnosis of orbital neoplasms. Vestn Oftalmol 2008;124:39-41.

11 Reddy AR, Chang BYP, Bradbury JA. Is this really a capillary haemangioma? Orbit 2007;26:327-329. 